\title{
ДО ЮВІЛЕЮ МИКОЛИ ДМИТРОВИЧА ЧЕМИЧА
}

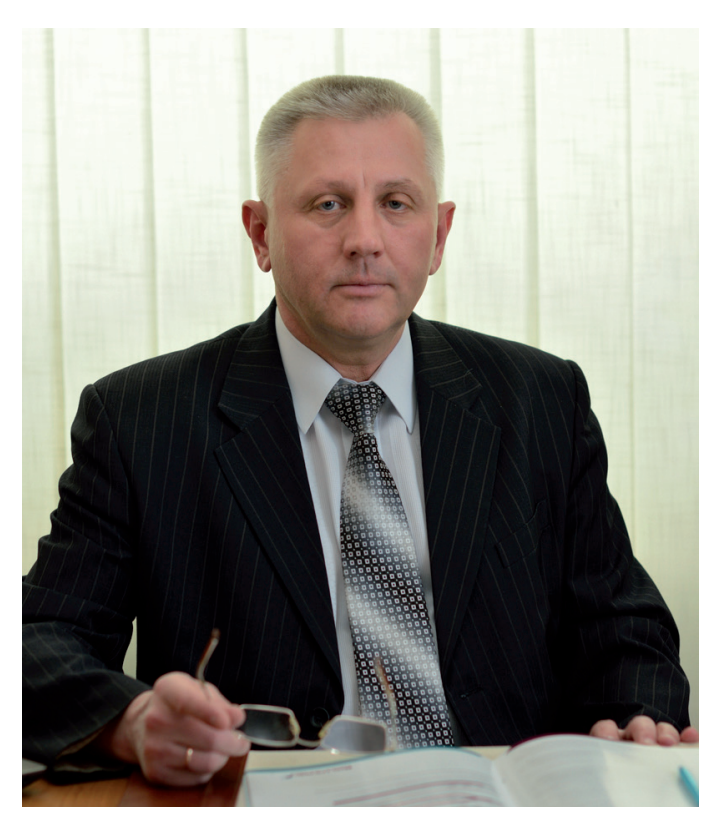

Дана коротка біографрічна інфрормація про українського вченого-інфрекціоніста, керівника Сумської обласної клініки інфрекційних хвороб, завідувача кафредри інфрекційних хвороб з епідеміологією Сумського державного університету, члена редакційної колегії Всеукраїнського науково-практичного медичного журналу «/нфрекційні хвороби», профресора Миколу Дмитровича Чемича.

Чемич Микола Дмитрович - доктор медичних наук, профресор, заступник президента ГО «Всеукраїнська асоціація інфекціоністів», голова ГО «Асоціація інфрекціоністів Сумщини», лікар-інфекціоніст вищої категорії, керівник обласної клініки інфрекційних хвороб, завідувач кафедри інсекційних хвороб з епідеміологією Сумського державного університету, яка з моменту ії створення є організаційнометодичним, навчальним і науковим центром інсрекційної служби області. Загальний стаж роботи понад 40 років, за спеціальністю - 33.

Микола Дмитрович народився 16 липня 1957 р. в с. Демківці на Хмельниччині в селянській родині. Вищу медичну освіту здобув у Тернопільському державному медичному інституті, який закінчив з відзнакою у 1984 р., після чого навчався у клінічній ординатурі та аспірантурі на кафредрі інфекційних хвороб з епідеміологією ТДМІ, де до 1994 р. працював асистентом.
Подальша практична діяльність ювіляра пов'язана 3 Сумським державним університетом, у якому разом 3 3.Й. Красовицьким став організатором кафедри інфекційних хвороб з епідеміологією. 31994 р. працює на посаді доцента, з 2002 р. - завідувача кафредри інфекційних хвороб. В 1994-2008 рр. був заступником директора медичного інституту СумДУ з лікувальної роботи та післядипломної освіти, один з організаторів фракультету післядипломної медичної освіти.

Активно проводить лікувально-консультативну роботу в клініці, організував консультативну допомогу в лікувальних закладах міста і області. Брав участь у локалізації епідемічних спалахів дифттерії, шигельозів, мікоплазмозу, грипу як в Україні, так і за її межами (Таджикистан, 1988 р.). За його участі вперше в Україні встановлено діагноз холери, спричиненої сероваром О139, діагностовано та проліковано низку екзотичних захворювань (лейшманіоз шкірний та вісцеральний, амебіаз, тропічна малярія тощо). Здійснюється постійна робота з вивчення та локалізації природного осередку опісторхозу та бореліозу. 31994 р. є постійним консультантом територіального центру екстреної медичної допомоги.

Наукові здобутки ювіляра: кандидатська дисертація «Клініко-патогенетична оцінка і корекція порушень кровотоку слизової оболонки шлунка та його функцій при харчових токсикоінсрекціях (1990р., керівник профресор М.А. Андрейчин), докторська дисертація «Клініко-епідеміологічні та патогенетичні особливості шигельозу, оптимізація лікувальних заходів (2006 р., консультант професор М.А. Андрейчин). Співавтор монограсрії «Класифрікація інсрекційних та паразитарних хвороб», двох видань посібника «Діагностика, терапія інфекційних хвороб в умовах поліклініки», двотомного видання «Довідник фельдшера», національного підручника 3 інфекційних хвороб, ряду посібників та методичних рекомендацій. Має понад 500 друкованих праць, 8 авторських свідоцтв на винахід, ряд свідоцтв на раціоналізаторські пропозиції з удосконалення лікування. Входить до складу спеціалізованої вченої ради з розгляду та захисту дисертацій на здобуття наукового ступеня доктора (кандидата) медичних наук при ВНМУ імені М.І. Пирогова. За його керівництвом на кафредрі виконано і захищено 2 кандидатські дисертації, здійснюються підготовка магістрів, керівництво аспірантами.

Протягом 30 років виховує молоде покоління лікарів і науковців, зарекомендувавши себе високодосвідченим 


\section{ЮВІЛЕї ТА ПОДІї}

педагогом. Підготував значну кількість лікарів-інфеекціоністів, клінічних ординаторів, які працюють не лише в Україні.

Постійно впроваджує в лікувальний процес нові методи лікування і діагностики інфекційних хворих. Був ініціатором і безпосередньо розробляв і продовжує впроваджувати програму «Антигепатит», яка дає вагомі економічні та соціальні здобутки. Постійно організовує Всеукраїнські та обласні науково-практичні конференції, присвячені проблемам інфектології.

Неодноразово нагороджений грамотами Асоціації інфекціоністів України та грамотою МОЗ України, відзначався подяками УОЗ Сумської облдержадміністрації. Нагороджений пам'ятною медаллю Асоціації інфекціоністів України Агапіта Печерського «За внесок у боротьбу з інсрекційними хворобами».

Микола Дмитрович має безперечний авторитет і повагу серед освітянської і медичної спільноти, співробітників лікарні, кафедри, професорсько-викладацького складу університету. Йому властиві сумлінне відношення до своїх обов'язків, ініціативність, відповідальність, висока працездатність, дисциплінованість, уважне ставлення до підлеглих, пацієнтів, студентів.
16 липня 2017 р. виповнюється 60 років Миколі Дмитровичу. Інфрекціоністи України і співробітники кафредри інфекційних хвороб з епідеміологією Сумського державного університету, колектив Сумської обласної інфекційної клінічної лікарні імені 3.Й. Красовицького поздоровляють Миколу Дмитровича Чемича з ювілеєм, зичать доброго здоров'я, плідної профресійної діяльності, любові і добра.

Президія Всеукраїнської Асоціації інфрекціоністів, колектив кафедри інфекційних хвороб Сумського державного медичного університету, редакція журналу «Інфрекційні хвороби».

\section{TO THE ANNIVERSARY OF PROFESSOR MYKOLA DMYTROVYCH CHEMYCH}

SUMMARY. Short biographic information is exposed about the Ukrainian scientist-infectiologist, leader of the Sumy Regional Clinic of Infectious Diseases, manager of the Department of Infectious Diseases with Epidemiology of Sumy State University, member of editorial college of the All Ukrainian research and practice medical journal Infectious Diseases, Professor Mykola Dmytrovych Chemych.

Отримано 19.05.2017 р. 